\title{
A framework for the construction of academic communities
}

\author{
Marco de referencia para la construcción \\ de comunicades académicas
}

\author{
Carlo Granados Beltrán1
}

\section{Abstract}

This article aims to explain how an academic community can be constructed based on teaching and research. For this purpose, first of all, a definition of academic community is provided; secondly, the way in which the building of this community can be done by fostering cooperative work, reflective teaching and teacher autonomy is described. In addition, the means by which students can take more active participation in this construction by engaging in critical thinking, learner autonomy and the implementation of a curriculum as inquiry are explained. Finally, some tasks for the academic community are specified as well as its impact on the institutions and on the field of language teaching.

\section{Keywords}

Academic community, reflective teaching, autonomy, inquiry, action research.

\section{Resumen}

Este artículo tiene por objeto explicar cómo se puede construir una comunidad académica a partir de la enseñanza y la investigación. Para dicho fin, se explica, en primera instancia, qué se entiende por comunidad académica; posteriormente, se describe cómo -con base en el trabajo cooperativo- la enseñanza reflexiva y el fomento de la autonomía del docente, los profesores pueden contribuir a la construcción de comunidad académica. Asimismo, se explica cómo los estudiantes pueden tomar un papel más activo en la formación de esta comunidad mediante el fomento del pensamiento crítico, la autonomía del aprendiz y la implementación del currículo como investigación (curriculum as inquiry). Por último, se explica cuáles serían algunas de las tareas de esta comunidad y su impacto en las instituciones y en el campo de la enseñanza de idiomas.

\section{Palabras clave}

Comunidad académica, enseñanza reflexiva, autonomía, investigación reflexiva, investigación-acción.

Artículo recibido 21 de Julio de 2009 y aprobado el 16 de octubre de 2009

1 MA in Applied Linguistics, MA in British Cultural Studies and ELT. Full-time professor at Universidad Central. Bogotá, Colombia. Correo electrónico: cgranadosb@ucentral.edu.co 


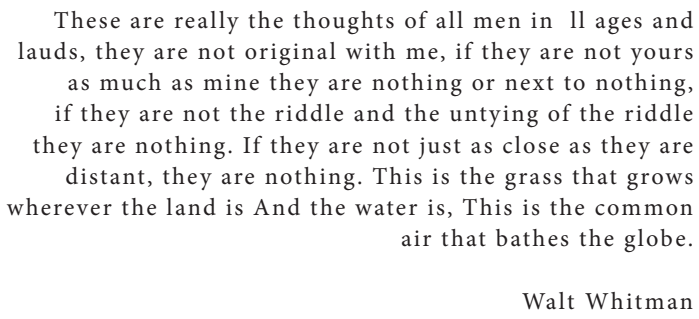

These are really the thoughts of all men in 11 ages and lauds, they are not original with me, if they are not yours as much as mine they are nothing or next to nothing,

if they are not the riddle and the untying of the riddle they are nothing. If they are not just as close as they are distant, they are nothing. This is the grass that grows wherever the land is And the water is, This is the common air that bathes the globe.

Walt Whitman

\section{Song of Myself}

I started by citing poem 17 of Song of Myself by Walt Whitman because it describes clearly what I understand by community and it also serves to explain the underlying assumptions of this framework.

The poem begins by saying "These are really the thoughts of all men in all ages and lauds, they are not original with me." This proposal tries to give account not only of what I think as a teacher, but also of the reflections I did after discussions with my colleagues 'in all ages and lauds.' This is the result of informal talks I have had with teachers in public and private education, teachers in formal and informal education, teachers for children, adults and teenagers.

The poem goes on saying "If they are not yours as much as mine, they are nothing or next to nothing." I do not understand this phrase as a representation of dogmatic fundamentalism in which everyone has to believe what I believe. Instead, it signifies that I, as a teacher, will not be helping to a real construction of community if I do not offer a voice that represents my colleagues before the rest of the community to express what they really know, think and feel.

"If they are not the riddle and the untying of the riddle, they are nothing." The riddle here is the construction of an academic community but in the same definition there is the solution to the problem, a group of people working together towards a specific goal: the construction of academy.

All institutions have an educational goal which is represented in the Colombian context by the Educational Institutional Projects (PEI) and their respective missions and visions. In any place there is an educational institution, there is the potential for the construction of a community. "This is the grass that grows wherever the land is and the water is;" 'the land and the water' are the teachers and the students working collaboratively and this work will result in 'the grass' that is the academic community.

Finally, "this is the common air that bathes the globe." First of all, many of the aspects I included here are the trends for language education nowadays in many parts of the world; and second, an institution with a sense of community works as a snowball that triggers the development of communities in other institutions creating the 'common air' of real academic discussions for the sake of the construction of knowledge.

Whitman very clearly states in this poem how an individual can contribute to the general sense of community. This leads us now to think about how we as professional individuals can construct an academic community, but first of all, we need to move from the general sense Whitman provided of community to the more specific concept of academic community.

\section{What is an academic community?}

Initially, I consider we should define exactly what we are talking about when we refer to an academic community. On the one hand, a community is considered as a group of people that live under certain rules and constitutions and who work for the achievement of a common goal. On the other hand, academic refers to a quality inherent to a scientific, literary, artistic or professional society having public authority. In brief, I would define an academic community as a group of professionals and students who work towards the same goal, that is, the academy: the construction of knowledge by means of dialogue and reflection.

It sounds well in theory, but it is exactly here where the problem lies since we as teachers, due to different factors such as time constraints, the covering of syllabus and sometimes personal differences, are not working together for the greater good. Instead, we limit ourselves to what we can possibly do in our own classrooms; therefore, the sense of community is lost. Additionally, we are not aware of or we resigned ourselves to discarding the labour we do as a profession, and to consider it just as an occupation with neither object of study nor scientific quality.

The idea in this paper is to present a framework in which we can observe how an academic community could be constructed based on the areas of teaching and research by engaging both teachers and students in activities related to reflective teaching, processes of inquiry, critical thinking and action research among other aspects.

\section{How do we construct an academic community by means of teaching? What can teachers do?}

Let us consider first the area of teaching. Teachers nowadays cannot keep stagnant in the explanation of grammar topics; we are asked to explore and keep up-to-date with the latest developments. But how 
can we do this? By means of collaborative work. Most of us know that our colleagues, depending on the areas of their interest, read books, search for web pages and/or apply new techniques or ideas in their classes but, because of the reasons above mentioned, we are not able to share with others what we do.

Some good ideas to create that space of sharing which contributes to the formation of an academic community are the ones mentioned by Hudelson (2001). They are team teaching and professional book clubs. On the one hand, team teaching refers to two or more teachers being in charge of a course. They set objectives and plan their teaching together, in this way, each one of the members of the team can learn from the experiences of the other members. On the other hand, a professional book club is "a group of teachers that comes together voluntarily, chooses a book to read every month or so and then meets to discuss the book." (Hudelson, 2001). This activity helps to provide useful insights in our labour as teachers and, in our specific case, teacher educators. It becomes a way of professional development which does not demand excessive amount of time, since, as stated by the author, it requires meeting only an hour and a half each month, and besides it does not need much money as a formal professional training program would.

The second way to improve our quality as professionals is by implementing activities that lead us to reflection in our daily teaching. In this way we can enhance not only our teaching itself but also, we can run into topics for research, aspect we will talk about later. Using journals, diaries, and peer observations permits that the teachers distance themselves from teaching and have an objective view of what happens in the classroom.

Richards and Lockhart (1996) stated five assumptions in their book "Reflective Teaching in Second Language Classrooms." These were:
1. An informed teacher has an extensive knowledge base about teaching. If we clearly understand the different dimensions involved in our teaching, we will be able to make appropriate judgments and decisions about our work.

2. Much can be learned about teaching through self-inquiry. We as professionals in our field are able to establish our own knowledge and theories, rather than believing all that the experts say as the dogma. Besides, even though an external colleague may provide interesting and useful information, s/he may not be familiar with the institution and its internal policies and her/his appreciations might be mistaken.

3. Much of what happens in the classroom is unknown to the teacher. We very often do not perceive what is really going on in the classroom or how we make decisions. The techniques for self-inquiry and reflection offer a space to understand our classroom and to make informed decisions to improve our teaching.

4. Experience is insufficient as a basis for development. Many of the routines we apply in the classroom are unconsciously used and although, they may serve their purpose in the immediate time, they do not help to construct knowledge unless we reflect upon them.

5. Critical reflection can trigger a deeper understanding of teaching. Critical reflection involves evaluating our teaching experiences to make decisions and as a source of change. If we are aware of the nature of our teaching, we will be capable of determining the stage of our professional growth and improving the aspects that need to be changed.

Based on these assumptions, if we want to reflect on what we do as teachers, it is necessary that we implement certain routines in our classes, such as:

Table 1. Techniques for reflective teaching.

\begin{tabular}{|l|l|l|}
\hline \multicolumn{1}{|c|}{ Techniques } & \multicolumn{1}{|c|}{ Definition } & \multicolumn{1}{c|}{ How to include it } \\
\hline Teaching journals & A teacher response to teaching events. & $\begin{array}{l}\text { Take } 10 \text { minutes after class to write in the journal your personal reactions, } \\
\text { questions or observations about problems, description of significant } \\
\text { aspects and ideas for future analysis. }\end{array}$ \\
\hline Lesson reports & $\begin{array}{l}\text { Written accounts of lessons describing their main } \\
\text { features. }\end{array}$ & $\begin{array}{l}\text { Beforehand prepare your lesson report format and after the class, fill it in in- } \\
\text { cluding what happened in the lesson, the time spent and its effectiveness. }\end{array}$ \\
\hline Surveys and questionnaires & $\begin{array}{l}\text { Administering a questionnaire or applying a survey to } \\
\text { collect specific information about teaching or learning. }\end{array}$ & $\begin{array}{l}\text { Twice in the semester, administer a questionnaire to the students so that } \\
\text { they evaluate specific aspects of your class. }\end{array}$ \\
\hline Audio and video-recordings & Recordings of a lesson or part of a lesson. & $\begin{array}{l}\text { This can be used as an additional technique to support the findings you } \\
\text { obtained using the other ones since recording sometimes may provide } \\
\text { subjective information and can be disruptive. }\end{array}$ \\
\hline Observation & $\begin{array}{l}\text { Visiting a class to observe different aspects of tea- } \\
\text { ching. }\end{array}$ & $\begin{array}{l}\text { Have a close colleague observe your class on regular basis. S/he will proba- } \\
\text { bly see aspects that you do not see for being involved in teaching itself. }\end{array}$ \\
\hline
\end{tabular}


As we could see in the previous chart, many of the activities to reflect upon our teaching involve the collaboration of other people, either our colleagues or our students. In such a way, we are building a community which works for the improvement of the processes of teaching and learning. A community is based on a model of transaction, not transmission. Neither are the teachers just the recipients of theories created by experts to apply in their classrooms nor are their students the passive recipients of what we do in class. We are professionals that, through reflection and collaboration, can become experts who develop actual theories for our classrooms and also our students can have their say in what we do so that they become active members in the classroom community.

Another aspect to be included, which is closely related to reflective teaching, is autonomy but autonomy related to the teacher. We are able -in cooperation with others - to create our own knowledge, we are not obliged just to accept what is imposed; in addition, we are individuals who can pursue professional development by ourselves and not because someone tells us to do so. McGrath (2000) clearly explained these two components of teacher autonomy: On the one hand, there is teacher autonomy as self-directed professional development and, on the other hand, there is autonomy as freedom from control by others.

McGrath (2000) argues for the first aspect that, although self-directed activity has a moment of its own, it is usually fostered by an external force such as the participation in a teacher education programme. For the second aspect, he claims that to obtain freedom from the control by others, it is necessary to bear in mind the different constraints teachers may face under the macro level (decisions made outside the institution, by the government, for example, in which teachers do not have control) and under the micro level (internal institutional decisions which the teacher may be able to influence).

McGrath (2000) affirms it is this second aspect of autonomy the one that shows we teachers are not autonomous since we accept the decisions made by others no matter if they are bad or good for our specific contexts. The alternative which shows a higher degree of autonomy is not to subvert what is imposed just because we do not like it, but to generate an academic discussion in which there is an opportunity for negotiation and the exercise of independent judgement based on academic arguments that lead to improvement.
We, English teachers, can contribute to the construction of an academic community in different ways. First, by keeping up our good quality as language professionals in both language competence and pedagogical skills; second, by reflecting on what we do in our day-to-day job and -as knowledge is not constructed by itself but is built by discussion and cooperation- by sharing with our colleagues the reflections we do about our job. Third, we contribute to form an academic community by being autonomous people and critical thinkers who are able to evaluate what is better for the benefit of all.

\section{What can students do?}

Students also make part of an academic community, but sometimes they are underestimated and regarded just as the recipients of what we do. However, it is necessary to understand that when students start any academic programme, that does not mean they do not know anything. We have to account for the background knowledge they have gathered in their previous years of schooling and through other media. But what can they do to construct and become an active part of an academic community?

The first aspect is to become critical thinkers. Critical thinking is to take a position towards the world around you; this means that it not only involves a stance towards learning but also towards the society and the institutions. Of course, to make students think critically can only be done, at the beginning, with the help of the teacher since our educational tradition did not favour, until recent years, the inclusion of thinking skills in the curriculum and some students may not be trained in it (Paul \& Elder, 1996; Halvorsen, 2005; Fisher, 2001; Saíz, 2002).

Critical thinking, according to Atkinson (1997) involves three components: individualism, selfexpression and using language as a tool for learning. The students need to recognise themselves as individuals who possess knowledge and who may have an opinion about issues which are within their reach such as the classes as well as aspects beyond their reach, e.g. politics or economics.

Students, after having recognised themselves as individuals, need the space to share what they think and to have discussions with their teachers about what they themselves do or think; what their teachers do or think, their opinions about their object of study. That sort of discussion, along with the discussions among teachers, contributes to the sense of community. Finally, students need to use the language as a tool for learning; in special, the 
use of written language because it works as a tool for intellectual exploration and a way for debate and dialectic (Atkinson and Ramanathan, 1995). The use of journals and diaries by students trains them to be critical and to be able to support their opinions.

An experience that might serve as an example for the way to begin to introduce critical thinking in our classes is the one I had teaching an Advanced English class at Universidad Pedagógica. In that class, students were taught to write different kinds of essays: comparison and contrast, definition, argumentation, classification, and the like. I remember myself before checking their essays for its form, checking them for content and analysing what they had to say as individuals about different issues, such as race, politics, culture and evaluation. I asked them questions on their essays and these simple questions, as in the Socratic method, led them to think about what they were saying and, by answering my questions, they were obliged to argue their thoughts and consequently, to construct knowledge by themselves.

As a result, the construction of an academic community can be done by recognising the members of the community (students and teachers) as individuals with different ways of thinking and acting and by providing them with a space for sharing and justifying their thoughts and ideas. Unfortunately, critical thinking has been misinterpreted in its applications, in the sense that it has turned into the pervasive conception of client-oriented education in which students are always right, it does not matter if they are not. It is not my point here that students are the ones who learn and we teachers are the ones to teach. However, we need to acknowledge that most of the times students are not able to support their opinions. For example, students may not be able to explain the reasons why they are against an aspect of your class, or why they do not consider your teaching as suitable or why they think your methodology is not appropriate; in consequence, the true sense of critical thinking fails and ends up contributing to a state of anarchy and not to the formation of a community.

The second aspect is autonomy, but this time in relation to the learner. An autonomous learner, according to Holec (1981), is a learner who is able to take charge of her/his own learning. However, the trend has been to understand that learners become autonomous just by telling them to do so and -despite this has been changing in recent years (Finch, 2002; Legenhausen, 2007; Vieira et ál., 2008; Aoki, 2008) - we do not offer them the support they need to really become autonomous. Due to the fact in their previous studies, elementary and high school courses, some students were not asked to carry out independent work, it is necessary that the change of paradigm, from dependence to independence, must be done gradually in order to avoid chaos.

Also, we must understand that fostering autonomy is not solely the teaching of learning strategies, it involves several characteristics. Sinclair (1997) established thirteen principles to define autonomy:

1. Autonomy is a construct of capacity. The learner must be capable to make informed decisions about his/her learning. By involving reflective techniques such as journals or logs, students can become more knowledgeable about their processes.

2. Autonomy involves a willingness on the part of the learner to take responsibility for their own learning. The learner must have a positive attitude towards taking on more responsibility for her/his learning.

3. The capacity and willingness of learners to take such responsibility is not necessarily innate. The willingness to be in charge of our own learning is not inborn but it can be fostered through formal learning.

4. Complete autonomy is an idealistic goal. An individual being autonomous in all areas of life is utopian. The objective is to make students take more responsibility, not to have them take it all.

5. There are degrees of autonomy. There is a continuum for the development of autonomy and the degrees vary depending on different factors that can be affective, physiological, psychological or environmental.

6. These degrees are unstable and variable.

7. Autonomy is not simply a matter of placing learners in situations in which they have to be independent. Although self-direction is an important component in the development of autonomy, this cannot be developed without a psychological and methodological preparation.

8. Developing autonomy requires conscious awareness of the learning process, i.e. conscious reflection and decision making. Students need to know and use metacognitive strategies to reflect on their learning. Those strategies help to set goals, to self-assess progress, to evaluate learning activities and to exploit learning resources. 
9. Promoting autonomy is not simply a matter of teaching strategies: Evidently, teaching students learning strategies and how to use them is a key part in the development of autonomy, but it is not the only aspect that is to be considered. Learners also benefit from reflection of different issues that affect their learning such as attitudes, motivation, beliefs about learning, affective factors, sociocultural and political contexts. (Ellis and Sinclair, 1989)

10. Autonomy can take place both inside and outside the classroom. It is necessary to unveil the myth of the classroom as the only site for learning to occur; students can make decisions about their learning in programmes such as distance learning, blended learning courses and self-instruction.

11. Autonomy has a social as well as an individual dimension. Autonomy and knowledge are socially constructed, both the raising of awareness and the process of learning take place by interacting and collaborating with others. (Benson, 1996)

12. The promotion of learner autonomy has a political as well as a psychological dimension. This characteristic of autonomy is related to the issue of critical thinking mentioned previously. Autonomy contributes not only to the construction of academy as a community, but also to the construction of a country as a community. Autonomy is less about 'personal empowerment' than about contributing to society's economic health by developing the ability to adapt and keep up with the increasing pace of change and competition faced by that society. (Sinclair, 2000).

13. Autonomy is interpreted differently by different cultures. The roles of teachers and learners vary from culture to culture; therefore, what probably works well in a European context, may not work in a Latin American one. It is necessary to remember that all pedagogy is context-embedded. As Kumaravadivelu (2001) stated: "language pedagogy, to be relevant, must be sensitive to a particular group of teachers, teaching a particular group of learners pursuing a particular set of goals within a particular institutional context embedded in a particular sociocultural milieu."

How do we implement all this theory into our classrooms? First of all, it is necessary to bear in mind that all these aspects cannot be obtained all at once by the waving of a magic wand, and that autonomy is to be achieved gradually. Moreover, we should not change paradigms radically considering the scarce history of the development of autonomy in our education, if we do this, we risk misleading students to believe that the teachers do not have any function since they as students have to do it all by themselves. Additionally, we put in danger our labour by giving students too much freedom without guidance.

I will exemplify how autonomy can be developed gradually within our classes by citing again the course on Advanced English I mentioned previously. This course focused on writing essays. A colleague who was teaching a parallel course and I decided to give students a schedule along with a set of readings they had to do by themselves. They had to come to class not to read the texts but to have a discussion with the teacher and their classmates about what they have read. After clarifying their doubts, they were asked to write their corresponding essays and to ask a classmate for revision; they had to incorporate the feedback given by their mates, and then, to hand it in to the teacher who wrote his feedback, asked the students to incorporate it and finally, graded it.

How can autonomy be perceived here? As I stated before, changing paradigms too hastily leads to problems, but if we do that step by step, it works. In the example cited, the role of the teacher was no longer the one of the provider of knowledge but the one of guide, students read and constructed their knowledge by themselves and then, checked for questions with the teacher. Moreover, students were considered as individuals capable of helping their peers with their job, the inclusion of this simple routine in the classroom gives students confidence in taking more responsibility for their learning. They are learning with the teacher, not from the teacher. Also by having a pre-established schedule, they were trained into controlling time for handing in products so that later, they could do it by themselves. Of course, having made these changes somewhat empirically, there were some aspects we did not take into account at that moment such as setting the goals together with the students and training them in the use of strategies. The idea is that by giving each time more responsibilities to students, they are finally able to take charge of their learning.

This example I cited working with one of the highest levels does not mean that the encouragement of autonomy cannot be done since the initial 
courses. I consider that the fostering of autonomous learning could be outlined in terms of stages in which students are trained depending on their learning processes in specific learning strategies. The following chart is an attempt to display how it could work:

Table 2. Stages for the fostering of autonomous learning.

\begin{tabular}{|c|l|l|}
\hline Stages & \multicolumn{1}{|c|}{ Definition } & \multicolumn{1}{|c|}{ How to do it } \\
\hline $\mathbf{1}$ & $\begin{array}{l}\text { Reflection. Both the teacher and the students reflect on the ways } \\
\text { in which they learn. }\end{array}$ & $\begin{array}{l}\text { Questionnaires and surveys. Hadfield (1992) provides some useful for basic } \\
\text { levels. }\end{array}$ \\
\hline $\mathbf{2}$ & $\begin{array}{l}\text { Direct Strategies2: Students are trained in the use of direct } \\
\text { strategies. }\end{array}$ & $\begin{array}{l}\text { Activities in which they practice those strategies. Oxford (1990) offers sug- } \\
\text { gestions to apply in our classes. }\end{array}$ \\
\hline $\mathbf{3}$ & $\begin{array}{l}\text { Collaborative work. Students are asked to discuss with their } \\
\text { partners about the strategies they use to learn. Poor learners are } \\
\text { encouraged to work with successful learners }\end{array}$ & $\begin{array}{l}\text { Group discussions in class. Short presentations from successful learners } \\
\text { showing how they learn. }\end{array}$ \\
\hline $\mathbf{4}$ & $\begin{array}{l}\text { Indirect strategies. Students are trained in the use of indirect } \\
\text { strategies. }\end{array}$ & $\begin{array}{l}\text { Activities in which they practice those strategies. Both Hadfield (1992) and } \\
\text { Oxford (1990) present practical activities to use in class. }\end{array}$ \\
\hline $\mathbf{5}$ & $\begin{array}{l}\text { Metacognitive strategies. A specific practical training is given to } \\
\text { students in techniques to organise and evaluate their learning. }\end{array}$ & $\begin{array}{l}\text { Activities that involve students actively in their process of learning: setting } \\
\text { objectives together with the teacher, planning how to obtain these objectives } \\
\text { and self-monitoring and evaluating the process. }\end{array}$ \\
\hline
\end{tabular}

2 Oxford (1990) explains that, on the one hand, direct strategies are those directly related to language. These are subdivided in memory, cognitive and compensation, within these direct strategies, we can find creating mental linkages, practicing and guessing intelligently, among others. On the other hand, indirect strategies are not directly related to the target language but 'underpin the business of language learning.' They are subdivided in metacognitive, affective and social. Some examples of these strategies are arranging and planning your learning, lowering your anxiety and asking questions, among others. For more information, check Oxford (1990, pp. 136-149).

Although I established reflection as the first stage and collaborative work as the third one, I affirm that we could use them throughout the whole process to strengthen the training in strategies. The incorporation of journals and learning logs helps to the processes of reflection and awareness-raising in relation to the ways in which we learn. In addition, the discussions with classmates enhance the process; therefore, it would be useful that after each activity done in class, there is a group discussion to reflect about its usefulness and its practicality.

In addition, through the different activities we take to our classes, we can encourage the use of strategies. We take activities for each skill to our classes. Before we make students do the task, we can explain to them how to approach it; for example, how to use background knowledge or how to use pictures to activate schemata before a listening or a reading activity. It is necessary to mention that in the first stages, the students need a lot of support from the teacher in the organisation of their work, as I exemplified in my course, but the idea is that they grow increasingly autonomous so that in the fifth stage they can be more independent.

As mentioned before, fostering learner autonomy contributes initially to personal growth, but in the long run, having students participate in their own learning and in the decisions about the class trains them to participate in wider spaces, e.g. the institution and the country; in this way, they become active members in the academic community they make part of.

\section{Which would the results of the collaboration of teachers and students in teaching be?}

Obviously, the first result of this collaboration among teachers and students and the implementation of reflective techniques would be the construction of an academic community. But we cannot limit just to have a community which will become stagnant again by not doing anything. One of the first things that the academic community must do is to establish standards, that is, we have to answer: What is the profile of the professional we are forming? What conditions does he or she have to meet to be a good professional? In our specific case: What do we consider a good professional in foreign language teaching?

First, there would have to be an analysis of the current situation, that is, a diagnostic study of what our context really needs and second, a definition of the standards to be met by foreign language professionals. This certainly would include standards of the proficiency the new professionals should have in the foreign language as well as their pedagogical skills, but there are other aspects to be included. 
Kumaravadivelu (2001) determined some characteristics that both the teacher and the teacher trainer must have nowadays. Based on the characteristics he established, I specified the possible ways in which we could obtain those standards:

Table 3. Ways to achieve professional standards.

\begin{tabular}{|c|c|}
\hline $\begin{array}{l}\text { A good } \\
\text { teacher }\end{array}$ & How could we achieve it \\
\hline $\begin{array}{l}\text { Has good mastery of the } \\
\text { language s/he teaches. }\end{array}$ & An international exam. \\
\hline Is autonomous. & \multirow{6}{*}{$\begin{array}{l}\text { Rigorous observation to student teachers in } \\
\text { their teaching practice. }\end{array}$} \\
\hline $\begin{array}{l}\text { Engages in self-develo- } \\
\text { pment. }\end{array}$ & \\
\hline $\begin{array}{l}\text { Reflects upon her/his tea- } \\
\text { ching. }\end{array}$ & \\
\hline $\begin{array}{l}\text { Encourages autonomous } \\
\text { learning. }\end{array}$ & \\
\hline $\begin{array}{l}\text { Encourages collaborative } \\
\text { learning. }\end{array}$ & \\
\hline Fosters critical thinking. & \\
\hline $\begin{array}{l}\text { Does research with her/his } \\
\text { learners not on them. }\end{array}$ & $\begin{array}{l}\text { Assistance and evaluation by senior re- } \\
\text { searchers to the projects that the teachers } \\
\text { carry out. }\end{array}$ \\
\hline
\end{tabular}

Apart from the characteristics mentioned for the teacher, for the teacher trainer, he adds:

Table 4. Characteristics of a good teacher trainer.

\begin{tabular}{|l|l|}
\hline \multicolumn{1}{|c|}{ A good teacher trainer } & $\begin{array}{l}\text { How could we } \\
\text { achieve it }\end{array}$ \\
\hline $\begin{array}{l}\text { Recognises and helps student teachers to } \\
\text { recognise teachers as producers of knowled- } \\
\text { ge vs. teachers as consumers of knowledge } \\
\text { (transaction vs. transmission). }\end{array}$ & \\
\cline { 1 - 1 } $\begin{array}{l}\text { Provides the necessary conditions for pros- } \\
\text { pective teachers to acquire skills in discourse } \\
\text { analysis that will help them hypothesise from } \\
\text { their classroom practice to construct theory. }\end{array}$ & $\begin{array}{l}\text { Observation by colle- } \\
\text { agues. }\end{array}$ \\
\cline { 1 - 1 } $\begin{array}{l}\text { Connects the generic professional knowledge } \\
\text { provided by experts to the particular learning } \\
\text { teaching contexts that prospective teachers } \\
\text { are familiar with, that is, connects theory } \\
\text { and practice. }\end{array}$ & $\begin{array}{l}\text { Opportunities for self- } \\
\text { development and pro- } \\
\text { fessional updating. }\end{array}$ \\
\hline
\end{tabular}

These are some working criteria that we can use, but it is the whole academic community of language teaching professionals that, based on our specific context, determines what is needed from the future language professionals, in collaboration with the communities in other institutions. This is a process which has already started by means of the National Bilingualism Project and the adoption of the Common European Framework of Reference for Languages as a proficiency indicator. However, it is still contentious how these standards and how the bilingualism project really adjust to and reflect our specific context and reality.

The second part of this article has to do with the ways in which the academic community nurtures the processes of research. Here I will consider aspects such as inquiry, lines of research and action research.

\section{How do we construct an academic community by means of research? What can teachers do?}

Most of the techniques I cited for reflecting upon our teaching help us also to discover questions for possible research projects. Everytime we ask ourselves "Why did that not work?" or "Why did that work?" or "How can I do X?", we are asking possible questions to investigate. That is why reflective activities as the lesson reports and teaching journals are useful in research. Moreover, based on the observations done by our colleagues, we can set projects about "How to improve..?" The results of our study will apply to our specific context, but they will be generalisable as long as we are rigorous in our study and as a result, we, as language professionals, become theorists who provide useful insights for colleagues in a similar situation.

However, the idea is not just to have the questions but to develop research projects. Research does not require very sophisticated training; in fact, we can do it in our classrooms. Hubbard and Power (1999) made a distinction between the Big ' $R$ ' and the little 'r'. On the one hand, the Big R refers to objective, large-scale studies with distant analysis of issues; this kind of research cannot be carried out by individual teachers due to institutional, time and money constraints. On the other hand, there is the little ' $r$ '; it refers to the research that focuses on the problems teachers are trying to solve in their classrooms. Research involves collecting and analysing data as well as presenting it to others in a systematic way, but it also comprises the skills and classroom activities that are already part of the classroom environment. This teacher research has as a main goal helping us to understand our students to improve our practice in specific ways.

This type of research is called action research. It is carried out by practitioners rather than external 
researchers, it is collaborative and it is aimed at changing things. Kemmis and McTaggart (1988) as well as Richards and Lockhart (1996) defined the different stages of action research. First, there is the initiation stage where the researcher identifies the issue, problem or particular interest and starts a preliminary investigation, that is, the search for facts in reference materials, previous studies, and the like. After this step, based on his/her exploration of facts, the researcher designs a plan of action which subsequently, he or she will apply with the help of the participants; then, the researcher has to observe the effects of the action on the participants and he or she has to reflect upon his/her plan. Taking into account this reflection, there must be a follow-up in which the plan is revised and modified to start the cycle again. Figure No. 5 which describes Lewin's model for action research shows clearly how it works:

Graphic 1. Lewin's model for action research.

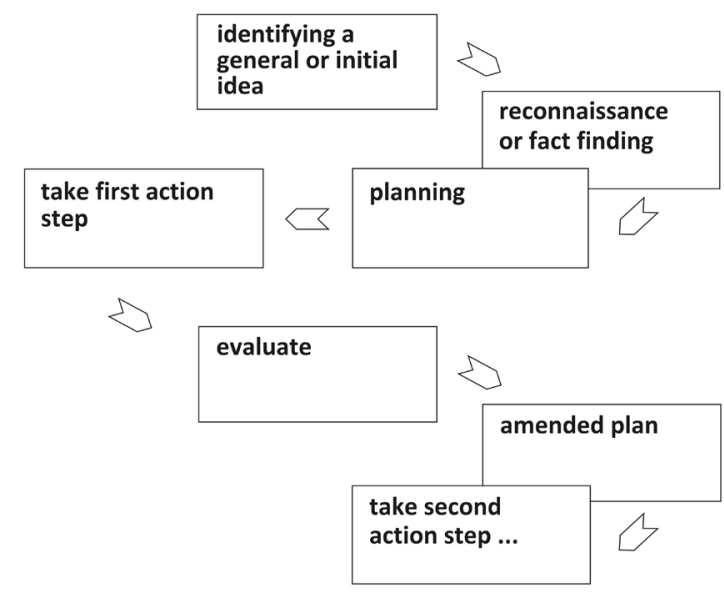

Extracted from: http://www.infed.org/research/b-actres.htm

Action research increases teacher's understandings of classroom teaching and learning and brings about change in classroom practices. It is collaborative, therefore, it contributes to the sense of community and as it leads us to construct knowledge; it also fosters the sense of academy. It is valuable since it gives hints for particular contexts, and it is not the confirmation of general theories established by experts.

This inclusion of action research will help teachers without experience in research to start the process. But what happens with the teachers that have long-time experience as investigators? These teachers, due to their experience, could develop projects of the 'Big R' kind that improve the quality of the academic community. Also, they would be the main source of help for the teachers who are just starting the process of becoming researchers.

Additionally, as each teacher will be developing an action research project, the group of experienced researchers could work as 'talent-hunters. They can discover the teachers that are particularly skilful and link them to the 'Big R' projects that they are pursuing. In such a way, the classroom turns not only into a space for teaching, but also, in a 'breeding ground' to create both teacher and student researchers.

Another aspect that teachers as English language professionals need to consider in the conformation of an academic community is the establishment of areas of research. These are established when there is a research project going on in that area. In the context of Colombian professional language teaching, there are areas that need to be studied, namely: Colombian ELT and professional standards, ELT in primary and high school education, pedagogy for the democracy, critical thinking, ELT at university level, among others.

In these areas of research, it is necessary that the academic community follows a model that provides useful insights for the field. Despite there has been a long debate on the advantages of following qualitative and quantitative paradigms (Miles and Huberman, 1994; Duff, 2006; Dörnyei, 2007), it is necessary to move beyond this 'dichotomy' and follow a model which accounts for what really happens in the classroom and which serves better the purposes of human sciences.

Moreover, the work done in English needs to be done in all the other areas. All the components in the curriculum are intertwined and therefore, the knowledge obtained in areas such as linguistics, pedagogy, literature and other languages (such as French) can enrich the labour done in English. As established by Halliwell, S. (1992) real life does not present us with knowledge in compartmentalised packages; thus, it is necessary to begin connecting the different areas in the curriculum by means of teaching and research.

\section{What can students do?}

Students can also engage in research with the help of teachers. This can be done in all the subjects throughout the curriculum by means of inquiry. Inquiry is based on the following principles, stated in Short and Kauffman (1992) and Short et ál. (1996): 
1. In order for learning to occur, learners need to pose their own questions. When these questions arise, a cycle of inquiry is started and in it, learners form ideas and/or hypotheses and then act on those ideas to observe what happens.

2. Inquirers need to be problem-posers, not only problem solvers. The questions learners pose need to be significant for them, otherwise, the processes of problem solving and research are useless.

3. Inquiry does not narrow the perspective. It provides more understandings, questions and possibilities than when the cycle is started. It is not just posing and answering a question. It comprises looking for meaningful questions and figuring out how to explore them from different perspectives.

4. Three sources of knowledge are important to inquirers in their search for significant questions and their investigation. These are personal and social knowledge, knowledge systems and sign systems. We obtain personal and social knowledge from experiences throughout our lives. Knowledge systems provide structures for the organisation of knowledge (history, biology, psychology). Sign systems provide alternative ways of creating meaning about the world (art, music, language, and maths). These systems are considered not as discrete-subject areas, but as ways of thinking and stances we can take in the world.

5. Learners will not pursue the questions that are really important for their lives unless they have a supportive environment in which their ideas and lives are valued. The most supportive environments are the ones which foster a horizontal rather than a vertical relationship among students and teachers. An environment in which each of them is considered as an autonomous individual.

6. Inquiry is a whole process that moves across and integrates personal and social knowing, knowledge systems and sign systems within an environment based on education for democracy.

The cycle of inquiry starts with building from students' own previous experience and knowledge so that they can draw connections to inform their inquiry. Then, from these personal connections, students move into wider explorations of the topic by observing, conversing and browsing a wide range of materials. Through this exploration, they build new understandings about the topic and gradually search for new questions to pursue by further inquiry. Once they have selected the question they want to pursue more thoroughly, they analyse the question through different perspectives. They carry out this analysis by thinking collaboratively with other learners, by investigating the questions with different knowledge systems and by using a wide range of sign systems to construct meanings. A graphic representation of this cycle is provided in Figure 6, taken from Short et ál., 1996, pp. 18.

Graphic 2. The inquiry cycle.

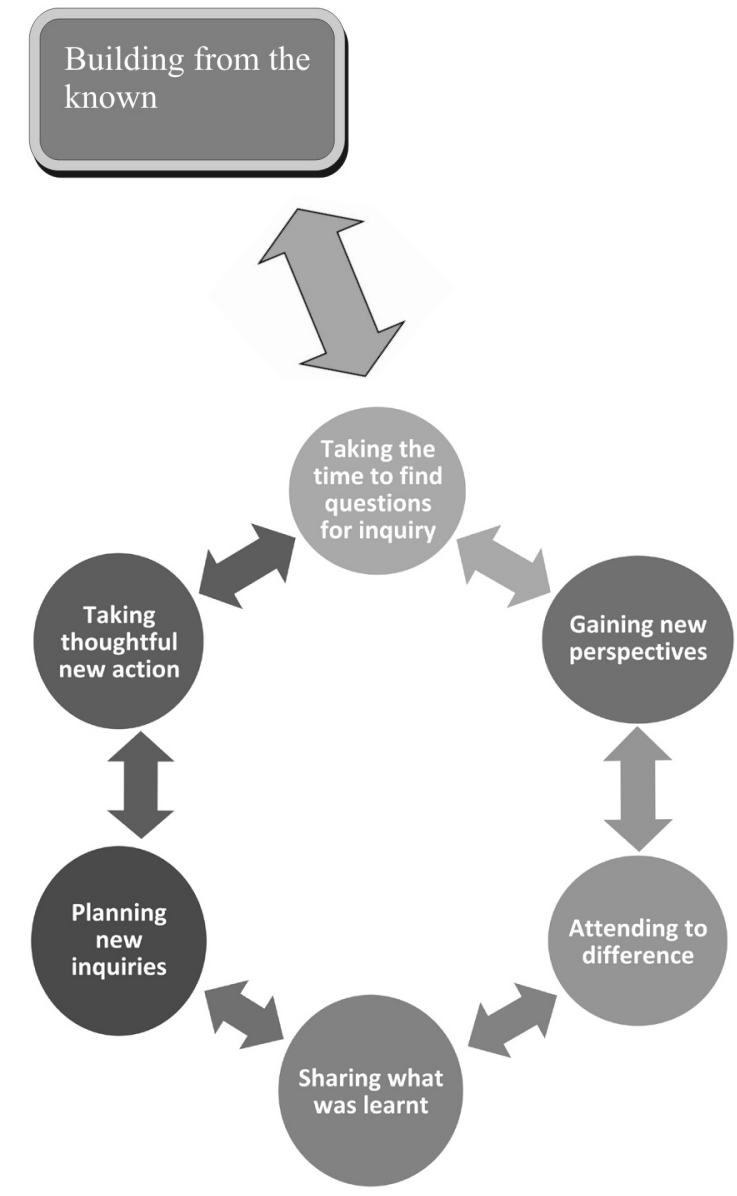

Extracted from Short et ál., 1996, 18.

This approach of inquiry has been mainly used with children in school age but I do consider it can work as a good way to involve research in the university classrooms. It is not only meaningful for students and helps them construct knowledge by themselves, but also it refines their skills as 
researchers without the burden of engaging them in more complex research processes since the very beginning.

How to implement inquiry in real life? I will cite the example of the new curriculum at Universidad Pedagógica. In this curriculum, all the contents of the subjects (espacios académicos) are 'core problems' (núcleos problemáticos) stated by means of questions. For example, for English Language and Culture 5, which was the course I taught, the questions were:

- In which way can we widen the range of registers for the use of English in communicative situations and be fluent and effective in those situations?

- How do we assume the foreign language learning as a process in continuous development in and out of the academic context?

- How do we identify and use the cultural differences between English-speaking and Spanish-speaking communities in order to enrich learning?

Nevertheless, there was a lack of coherence between what was proposed and with what I did since I had to cover the topics and the functions established in the syllabus and they did not clearly relate to the questions mentioned before. Besides, we used a book which did not contribute to answer those questions. However, I consider this could be a first step towards the inclusion of research in the classroom and to engage students in it.

Initially, what we could do is to refine the questions to make them more manageable for both students and teachers; subsequently, and to begin by making gradual changes, to involve students in the process by having them think about the possible sub-questions that contribute to the solution of the main questions. Finally, there is the need to relate

\section{Bibliografía}

Aoki, N. (2008). Teacher stories to improve theories of learner/teacher autonomy. Independence, 43, 15-17. Extraído desde http://www.learnerautonomy.org/ aoki2008.pdf theory and practice in a better way so that they nurture mutually, as it was stated in the section of standards for language teaching.

Another way in which students can be involved in research is the creation of 'breeding grounds' in our classrooms. As we will be developing action research projects, we may identify students who are skilful in research and ask them to join the project as 'junior researchers;' as a consequence, in the future, they will be very well trained as to continue the job carried out by the 'senior researchers' and develop their own investigations.

\section{Which would the results of the collaboration of teachers and students in research be?}

The idea is that the community where this proposal is implemented becomes a leading interdisciplinary professional research group that provides useful insights for other communities -certainly bearing in mind particular contexts- in terms of language study and language teaching methodology. We are the ones to become the experts and professionals in our field through study and research.

In addition, the institution, with the help of the academic community, will become capable of collaborating in the processes of evaluation of and assistance to other institutions in their professional improvement. Being an academy devoted to teacher training and having established the standards, this academic community will have the knowledge to assess and help institutions to construct better programmes, to train better teachers and to become more autonomous.

Finally, the institution will be able to offer programmes for further development addressed to in-service teachers in different areas such as research skills, reflective teaching, critical thinking and autonomy, among others. This will confer the academic community the public authority it needs to have. \?

Atkinson, D. (1997). A critical approach to critical thinking in TESOL. TESOL Quarterly, 1, 71-94.

Atkinson, D. y ramanathan, V. (1995). Cultures of writing. An ethnographic comparison of L1 and L2 university 
writing/language programmes. TESOL Quarterly, 29, 539-568.

Benson, P. (1996). Concepts of autonomy in language learning. En R. Pemberton et ál. (ed.), Taking control: autonomy in language learning. Hong Kong: Hong Kong University Press.

Dörnyei, Z. (2007). Research methods in applied linguistics. Oxford: Oxford University Press.

Duff, P. (2006). Beyond generalizability: contextualization, complexity, and credibility in applied linguistics research. En M. Chalhoub-Deville, C. Chapelle y P. Duff (ed.), Inference and generalizability in applied linguistics: multiple perspectives. Amsterdam: John Benjamins.

Elder, L. y Paul, R. (1996). Critical thinking development. A stage theory. Extraído desde http://www.criticalthinking.org/

Ellis, G. y Sinclair, B. (1989). Learning to learn english. Cambridge: Cambridge University Press.

Finch, A. (2002). Autonomy: where are we? Where are we going? Extraído desde http://www.finchpark.com/ arts/Autonomy.pdf

Fisher, A. (2001). Critical thinking: an introduction. Cambridge: Cambridge University Press

Hadfield, J. (1992). Classroom dynamics. Resource books for teachers. Oxford: Oxford University Press.

Halliwell, S. (1992). Teaching English in the Primary Classroom. Longman.

Halvorsen, A. (2005). Incorporating critical thinking skills development into ESL/ EFL courses. En The Internet TESL Journal, 3. Extraído desde http://iteslj. org/Techniques/Halvorsen-CriticalThinking.html

Holec, H. (1981). Autonomy and foreign language learning. Oxford: Pergamon.

Hubbard, R. y Power, B. (1999). Living the questions. A guide for teacher researchers. York, Maine: Stenhouse Publishers.

Hudelson, S. (2001). Growing together as professionals. How. A Colombian Journal for English Teachers, 9, 20-26.
Kemmis, S. y Mctaggart, R. (1988). The action research planner. Victoria: Deakin University Press.

Kumaravadivelu, B. (2001) Toward a postmethod pedagogy. TESOL Quarterly, 4, 537-560.

Legenhausen, L. (2007). Classroom research in autonomous language learning. Independence, 42, 17-20.

McGrath, I. (2000) Teacher autonomy. En Learner autonomy, teacher autonomy: future directions. Edinburgo: Pearson Education Limited.

Miles, M. y Huberman, A. (1994). Qualitative data analysis. Thousand Oaks, California: Sage.

Oxford, R. (1990). Language learning strategies. What every teacher should know. Boston: Heinle and Heinle Publishers.

Richards, J. y Lockhart, C. (1996). Reflective teaching in second language classrooms. Cambridge: Cambridge University Press.

Saiz, C. (2002). Pensamiento crítico: conceptos básicos y actividades prácticas. Madrid: Pirámide.

Short, K. y Kauffman, G. (1992) Hearing students' voices: the role of reflection in learning. Teachers Networking. The Whole Language Newsletter, 3(11), 3-6.

Short, K. et ál. (1996). Learning together through inquiry. From Columbus to Integrated Curriculum. York, Maine: Stenhouse Publishers.

Sinclair, B. (2000). Learner autonomy: the next phase. En Learner autonomy, teacher autonomy: future directions. Edinburgo: Pearson Education Limited.

Smith, M. (1996, 2001, 2007). Action research. The encyclopedia of informal education. Extraído desde http:// www.infed.org/research/b-actres.htm.

Vieira, F. et ál. (2008). Teacher education towards teacher (and learner) autonomy. En T. Lamb y H. Reinders (ed.), Learner and teacher autonomy: concepts, realities and responses (pp. 217-235). Amsterdam-Philadelphia: John Benjamins Publishing Company.

Whitman, W. (2001). Canción de mí mismo-Song of myself. Bogotá: Panamericana Editorial. 